\title{
Climate change indicators software for computing climate change indices for agriculture
}

\section{Software Indicador del cambio climático para el cálculo de índices de cambio climático para la agricultura}

\author{
Francisco Bautista ${ }^{1 *}\left[\right.$, Aristeo Pacheco $^{2}\left[0\right.$, Inna Dubrovina ${ }^{3} \odot$ \\ ${ }^{1}$ Centro de Investigaciones en Geografía Ambiental, Universidad Nacional Autónoma de México; Antigua Carretera a Pátzcuaro 8701. \\ CP. 58190. Morelia, Michoacán, México. \\ ${ }^{2}$ Skiu, www.actswithscience.com \\ ${ }^{3}$ Institute of Biology, Karelian Research Center of RAS; Pushkinskatya str. 11, Petrozavodsk, Russian Federation, 185910. \\ *Corresponding author: leptosol@ciga.unam.mx
}

Scientific note received: March 01, 2018 accepted: November 11, 2018

\begin{abstract}
Climatic anomalies affect agricultural production, so the identification of climate change at the local level is a pressing task. The Intergovernmental Panel on Climate Change (IPCC) has generated indices that allow the identification of extreme climate events. Recent studies of weather and climate variation have increasingly used the climate extreme indices defined by the IPCC. This article dwells upon the ICC (climate change indicators) software written in the Java language which is a convenient tool for storing and processing large sets of daily weather data. The software allows the calculation of 27 climate change indices and four indices for growing vines. Built-in analytical tools help identify trends and climate anomalies on different time intervals. The application is additionally supplied with important functionality for statistical data processing and visualization. Tools that help analyzing climate change can foster wiser strategic decision-making in the management of agriculture and ecosystems.
\end{abstract}

Key words: Analytical tools, climate anomalies, extreme weather, trend analysis, weather data.

RESUMEN. Las anomalías climáticas afectan la producción agrícola, por lo que la identificación del cambio climático a nivel local es una tarea apremiante. El Panel Intergubernamental sobre Cambio Climático (IPCC) ha generado índices que permiten identificar los eventos climáticos extremos. En este artículo se trata sobre el desarrollo del software ICC (Indicadores del cambio climático). ICC es una herramienta conveniente para almacenar y procesar conjuntos grandes de datos meteorológicos diarios. El software permite el cálculo de 27 índices de cambio climático y cuatro índices para el crecimiento de la uva. Las herramientas analíticas integradas ayudan a identificar tendencias y anomalías climáticas en diferentes intervalos de tiempo. El software permite un rápido procesamiento y visualización de datos, es de fácil manejo y tiene una interfaz intuitiva. El conocimiento sobre el cambio climático puede fomentar una toma de decisiones estratégicas más sensatas en el manejo de la agricultura y los ecosistemas en general.

Palabras clave: Herramientas analíticas, anomalías climáticas, tiempo extremo, análisis de tendencia, datos del tiempo.

\section{INTRODUCTION}

Recent changes in the climate are noted for a high intensity and frequency (Shelffield and Wood 2011), as well as spatial and temporal heterogeneity. Specialists predict that climate change will multiply and amplify hazardous and extreme hydrometeorological phenomena causing emergencies and natural calamities (IPCC 2007, Heim 2015). In developing economies, weather hazards of hydrometeorological origin are fraught with catastrophic effects for agriculture and food security. Increased frequency and intensity of extreme climate events have serious implications for socio-economic security and human health (Sepannen et al. 2006). Since global climate change is an integral index of regional changes, identification of the climate change at the local and regional level is a pressing task. It is there, at local and regional 
scales, that specific measures are taken to mitigate and adapt to current climate change (Gbegbelegbe et al. 2014, Jahn 2015, Shannon and Motha 2015).

The World Meteorological Organization (WMO) declares the priority of studying climate extremes and taking actions to mitigate the impact of extreme weather events. Extreme weather events are more variable. That is why recent studies of weather and climate variation have increasingly used the derivatives of climate extreme indices (Karl et al. 1999). The Intergovernmental Panel on Climate Change (IPCC) has recommended using a set of indices for extreme climate events. The indices are calculated from preprocessed meteorological datasets (IPCC 2007, Peterson 2005).

The known complexities of big data processing and analysis are labor-intensity, occurrence of incomplete and inconsistent datasets, and computation errors (Hall et al. 2009). A possible solution is to create a software application that can quickly process daily temperature and precipitation data covering large time intervals. Some software products exist such as RClimDEX, ClimPACT or RclimTool (Zhang and Yang 2004, Alexander et al. 2013, Herrera 2014) written in the $\mathrm{R}$ language and designed for the computation of climate indices (Alexander et al. 2013, Herrera 2014). This article dwells upon the ICC (Indicators of Climate Change) software written in Java. The aim was to design and create a software that fulfills the following tasks for agriculture purposes: storage of meteorological datasets; calculation of climate change indices for various time series; calculation of indices for growing vines; analysis of climate change trends; analysis of deviations from the mean; analysis of climate anomalies.

\section{MATERIALS AND METHODS}

The ICC software was design conforms to the NMX-I-045-NYCE standard (SE 2005). The waterfall life cycle model was chosen. The programming language was Java, its benefits being operating system independence, high productivity, open source code. Eclipse was used as an integrated development environment for writing, testing and tuning modular cross- platform applications.

Other tools used were: a) Plugins generate the functionality permitting Eclipse to be optimized for the development of specific applications; b) Apache Derby is a 2 MB relational DBMS, owing to JDBC support Derby can be embedded in any Java-based solution. Derby DBMS is easy to install, deploy and use, supports the SQL syntax and the client-server mode; and c) Database managed by Derby DBMS was designed and developed to store information about meteorological datasets.

Equations for the calculation of indices, correlation and trend analysis were translated to algorithms for processing of the datasets stored in the DBMS. The results of calculations and analysis are visualized in table or graphics format through programming interfaces (Figure 1).

Minimum system requirements for ICC operation: $1 \mathrm{GHz}$ or higher Intel or AMD processor; $384 \mathrm{MB}$ dedicated RAM; VGA display with $1200 \times 800$ resolution and $32 \mathrm{MB}$ video memory; Java virtual machine (JVM) 1.8; for Windows OS - Windows Vista, 7, 8, 10; any versions of Linux and Mac OS supporting JVM v. 1.8 .

\section{RESULTS AND DISCUSSION}

ICC software is installed to the computer by the setup wizard (ICC.exe file) and the database and the system are located in a directory (C: ICC:). Once the installation is complete, a shortcut icon to ICC will be found on the desktop. ICC software can be run in English and Spanish, is user-friendly, providing a graphical environment consisting of a set of screens, pop-up tabs and icons. ICC main menu additionally offers a set of common tools such as Save, Copy Cut and Paste (Figure 2)

The 'File' menu provides information about the weather stations included in the ICC database in tabular form (Figure 3). Station search can be based on one or several fields of the table. There are options to enter data on a new station, as well as edit, duplicate or delete data of a selected station. For entering a new station, a window will be displayed requesting the input of general facts about the station (Reference, 


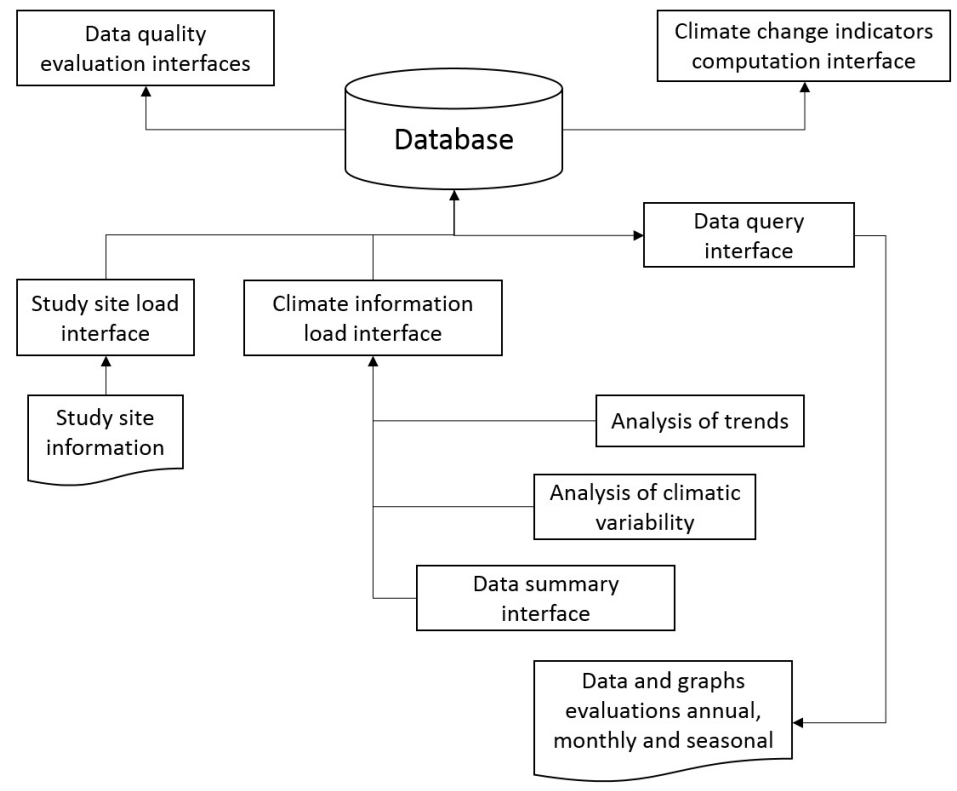

Figure 1. Conceptual diagram of ICC operation.

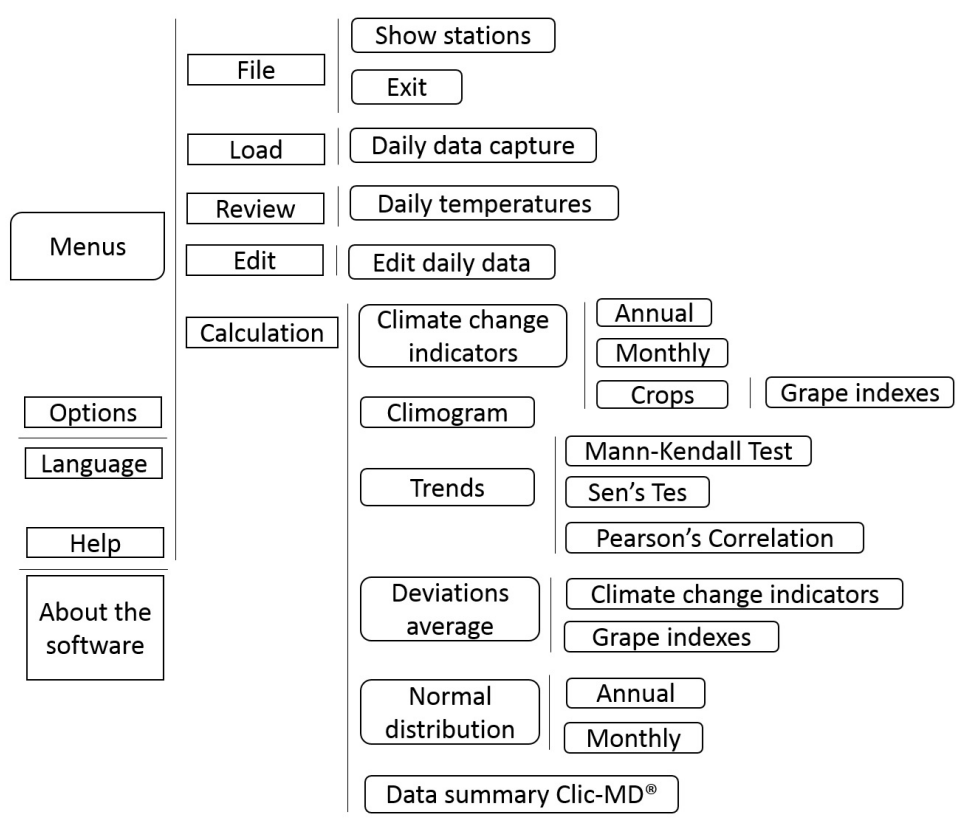

Figure 2. Diagram functionalities included in the software ICC main menu.

Name, Country, State, and Origin) and its geographical data (Latitude, Longitude, Altitude).

Activating the 'Load' menu one can capture data on mean, minimum and maximum temperature and precipitation at selected stations for a given time interval. Where some values are missing, the system will run an automatic recalculation from the average of the data from five days before and five days after the gap.

The 'Review' menu, allow open the window with daily temperature graphs for the chosen time interval and station, as well as export data in the form of 


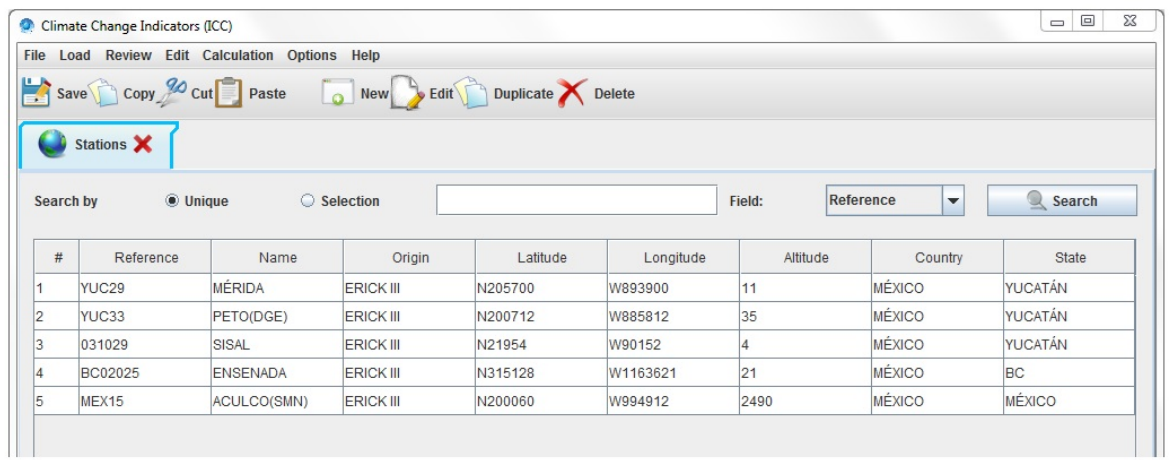

Figure 3. Weather station data in the ICC software order by column.

tables or text (.xls and .txt formats) or graphs (.pdf, .svg, .png formats). The 'Edit' menu can be used to make any changes to the data on mean, minimum and maximum temperatures and precipitation. There is also an option to remove a selected range of data. The 'Calculation' menu contains the key functions of the software. The necessary calculations can be selected from the drop-down tab menu.

ICC performs calculations for 27 core climate indices defined by IPCC (Karl et al. 1999, Peterson 2005), and an additional index DC40 (Consecutive days greater than or equal to $40^{\circ} \mathrm{C}$ ) (Bautista et al. 2015). The 'Calculation' menu contains the 'Climate change indicators' submenu. Unlike others softwares, with ICC each index can be calculated for a year- or a month-long interval or for a specific season (Figure 4). Calculation results are displayed in tables, which can be saved in the database or exported as .xls or .txt files.

ICC software unlike others features the function of calculating agroclimatic indices for growing vines (Table 1) (Alexander et al. 2013, Herrera 2014). Four indices are used to analyze the potential of certain regions for growing vines (Winkler et al. 1974, Ortiz-Solorio 1987, Gladstones 2002, Snyder et al. 2005). The 'Grape indices' submenu of the 'Calculation' menu should be chosen for this purpose.

A climate diagram can display data on the minimum, maximum and mean temperature and precipitation for two times intervals to be compared within a single graph (Figure 5). So far, this function is only possible in ICC. The data can be exported in graphics, table or text formats.

ICC allows calculating climate change trends by analyzing time series, just as other software does, the difference lies in the use of climate change indicators instead of climate elements (Table 2) (Zhang and Yang 2004, Alexander et al. 2013, Herrera 2014). The tests used for this purpose are Mann-Kendall test, Sen's test and Pearson correlation coefficient (Sen 1968, Kendall and Gibbson 1990). The degree of linear relationship between two variables is usually measured by the Pearson correlation coefficient. Correlation analysis can be used as a first approximation to detect changes in climate data and will work even for discrete data. The Mann-Kendall (MK) test is a non-parametric rank correlation coefficient. It is used to identify non-linear trends in 'nonGaussian' data series sampled at equal time intervals (Kendall and Gibbson 1990). Where the MK test displays a monotonous trend which appears linear, Sen's slope can be estimated to determine the trend in the dataset. These tests are robust against outliers, data gaps (lacunae) and non-normality.

The 'Trends overview' menu is useful for saving analysis time. It enables viewing data tables with summaries of climate change trends and choosing the indicators and / or months with changing trends to plot graphs only where changing trends were identified. In this menu one can select a range of years or months within a year for the chosen weather station, group indices into temperature or precipitation categories and pick out the necessary ones, run calculations for the selected time ranges and indices, and 


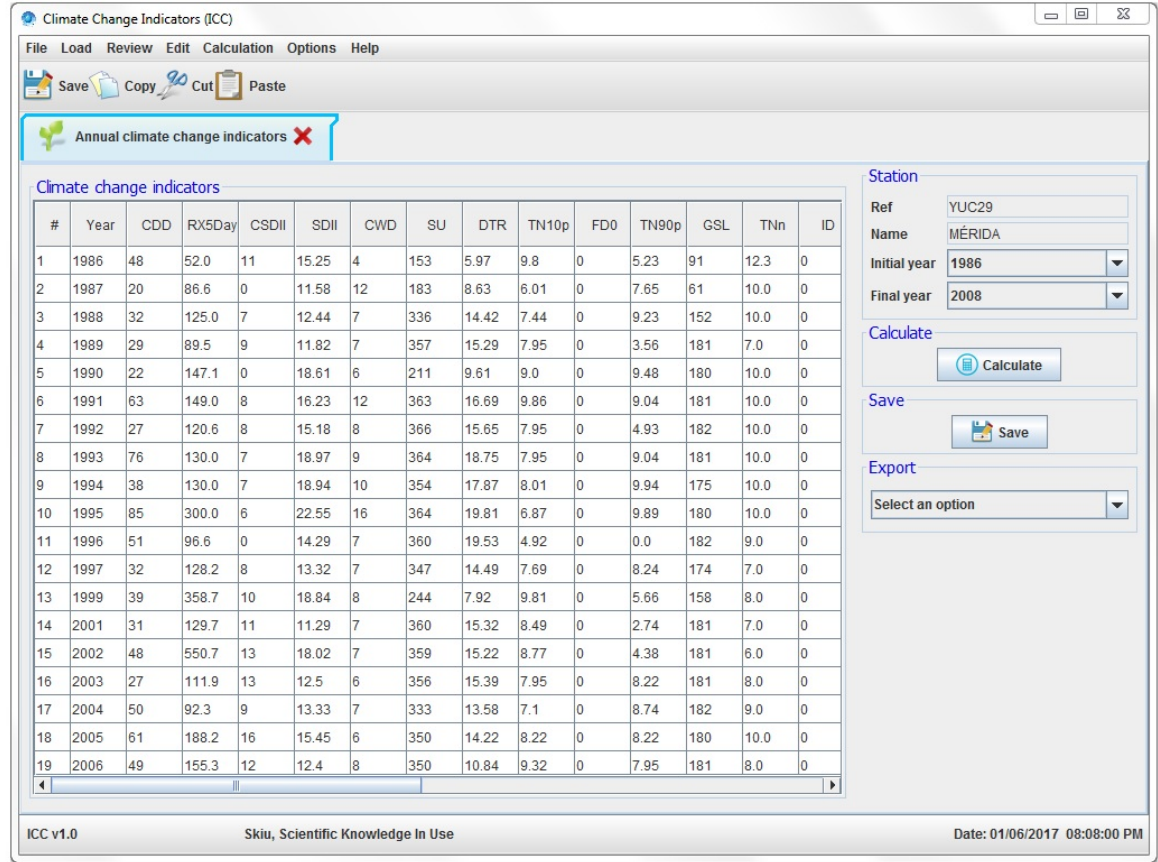

Figure 4. Annual climate change indicators in the ICC software defined by IPCC.

\begin{tabular}{|c|c|c|c|}
\hline $\begin{array}{l}\text { Designation, } \\
\text { units }\end{array}$ & Equation & Values & Origin \\
\hline $\begin{array}{l}\text { Growing degree } \\
\text { days, }{ }^{\circ} \mathrm{C}\end{array}$ & $\mathrm{GDD}=\sum \mathrm{Tm}-10$ & $\begin{array}{l}\text { Tm - average daily } \\
\text { temperature, }{ }^{\circ} \mathrm{C}\end{array}$ & $\begin{array}{l}\text { Winkler et al. } \\
\quad(1974)\end{array}$ \\
\hline $\begin{array}{l}\text { Frost-free } \\
\text { period, days }\end{array}$ & $\begin{array}{c}\text { PLH }=-2.009 \text { Tioa }^{2} \\
+52.658 \text { Tioa }+24.52\end{array}$ & $\begin{array}{l}\text { Tioa - average minimum temperature } \\
\text { for the period from October to April, }{ }^{\circ} \mathrm{C}\end{array}$ & $\begin{array}{l}\text { Snyder et al. } \\
\text { (2005) }\end{array}$ \\
\hline $\begin{array}{l}\text { Cold hours, } \\
\text { hours }\end{array}$ & $\mathrm{HF}=485.1-28.52 \mathrm{Tm}$ & $\begin{array}{l}\mathrm{Tm} \text { - average temperature for the } \\
\text { period from November to February, }{ }^{\circ} \mathrm{C}\end{array}$ & $\begin{array}{l}\text { Ortiz-Solorio } \\
\quad(1987)\end{array}$ \\
\hline $\begin{array}{c}\text { Average } \\
\text { maximum } \\
\text { temperature, }{ }^{\circ} \mathrm{C}\end{array}$ & $\mathrm{TMM}=\overline{T \max i j}$ & $\begin{array}{l}\text { Tmax - average maximum temperature } \\
\text { for the period from April to October, }{ }^{\circ} \mathrm{C} \\
i \text { and } j \text { - lower and upper analysis interval limit }\end{array}$ & $\begin{array}{c}\text { Gladstones } \\
\text { (2002) }\end{array}$ \\
\hline
\end{tabular}

remove the unnecessary data. The results can be exported as .xls or.txt files.

Only with the ICC software it is possible to plot the deviations to the average value of the indicators of climate change, this function is of great importance because it allows knowing the increases or decreases of each indicator of climate change over the years (Figure 6, Table 2). Graphs for climate indices can be plotted by opening the 'Calculation' menu, choosing the 'Graphics of increases and decreases' submenu and the item 'Climate change indicators' $A$ new tab will open, where one can choose the weather station, time range and index, data visualization options and then export graphical files in .pdf, .svg, .png for- mats. By choosing the 'Grape indices' item in the 'Graphics of increases and decreases' submenu, one can plot vines growing indices using data from the chosen weather station.

Another exclusive function of the ICC software is the identification of the anomalous values in climate change indicators and in the elements of the climate (Table 2). The 'Graphics of the annual / monthly normal distribution' menu is used to identify climate anomalies. This is done by investigating the difference between the means over the chosen period and the reference period considered as normal (usually a period before 1990) (IPCC 2007). Very high or very low values with $0.01-0.05$ probability of 
Bautista et al.

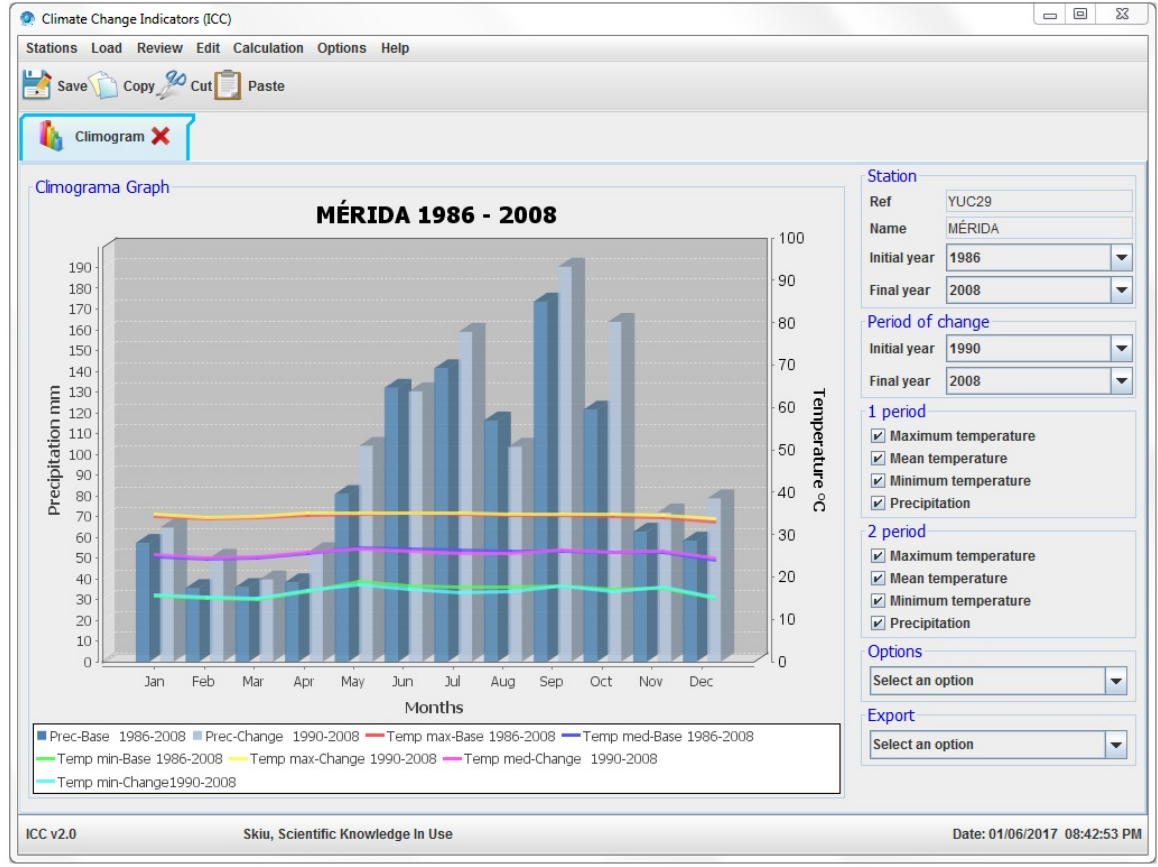

Figure 5. Climate diagrams of temperatures and precipitation on two periods using the ICC software.

Table 2. Comparison in the operation of the ICC software with other softwares.

\begin{tabular}{|c|c|c|c|c|c|}
\hline & Functions & ICC & RClimTool & ClimPACT & RClimDex \\
\hline 1 & Daily data analysis & Yes & Yes & Yes & Yes \\
\hline 2 & Analysis of monthly data & Yes & No & No & No \\
\hline 3 & Developed on $\mathrm{R}$ language & No & Yes & Yes & Yes \\
\hline 4 & Developed on Java language & Yes & No & No & No \\
\hline 5 & Data persistence (Database) & Yes & No & No & No \\
\hline 6 & Analysis of data series & Yes & Yes & Yes & Yes \\
\hline 7 & Calculation of climate change indicators annual & Yes & Yes & Yes & Yes \\
\hline 9 & Climate diagram for one or two time periods & Yes & No & No & No \\
\hline 10 & Review of temperatures graphically and tabularly & Yes & Yes & No & No \\
\hline 11 & Interface to modify the captured data & Yes & No & No & No \\
\hline 12 & Agroclimatic indices for the cultivation of the vine & Yes & No & No & No \\
\hline 13 & Trend analysis with Mann-Kendall and Sen's & Yes & No & No & No \\
\hline 14 & Summary of annual and monthly trends with Mann-Kendall and Sen's & Yes & No & No & No \\
\hline 15 & Friendly interface & Yes & No & No & No \\
\hline 17 & Export tabular data to *.csv format & No & Yes & Yes & Yes \\
\hline 18 & Export of graphic data to *.pdf & Yes & Yes & Yes & Yes \\
\hline 19 & Data capture based on a template & Yes & No & No & No \\
\hline 20 & Analysis of data homogeneity (Maximum, average, minimum and precipitation temperature) & Yes & No & No & No \\
\hline 21 & Analysis of homogeneity from other software (RHTest WMO) & No & Yes & Yes & Yes \\
\hline 22 & Available in Spanish and English & Yes & No & No & No \\
\hline 23 & Estimation of missing data & Yes & Yes & No & No \\
\hline 24 & ENSO conditions (EI Niño/Southern Oscillation) & No & Yes & No & No \\
\hline 25 & BoxPlot graphs and histograms to represent time series & No & Yes & No & No \\
\hline 26 & Data dispersion graphs (ICC also implements linear regression) & Yes & Yes & No & No \\
\hline 27 & Analysis of anomalies and extreme annual and monthly events & Yes & No & No & No \\
\hline 28 & Analysis of deviations from the mean in annual, monthly and seasonal temporality & Yes & No & No & No \\
\hline 29 & Based on Microsoft Excel & No & No & No & Yes \\
\hline 30 & Summary of daily to monthly climatic variables for Clic-MD ${ }^{\circledR}$ & Yes & No & No & \\
\hline
\end{tabular}




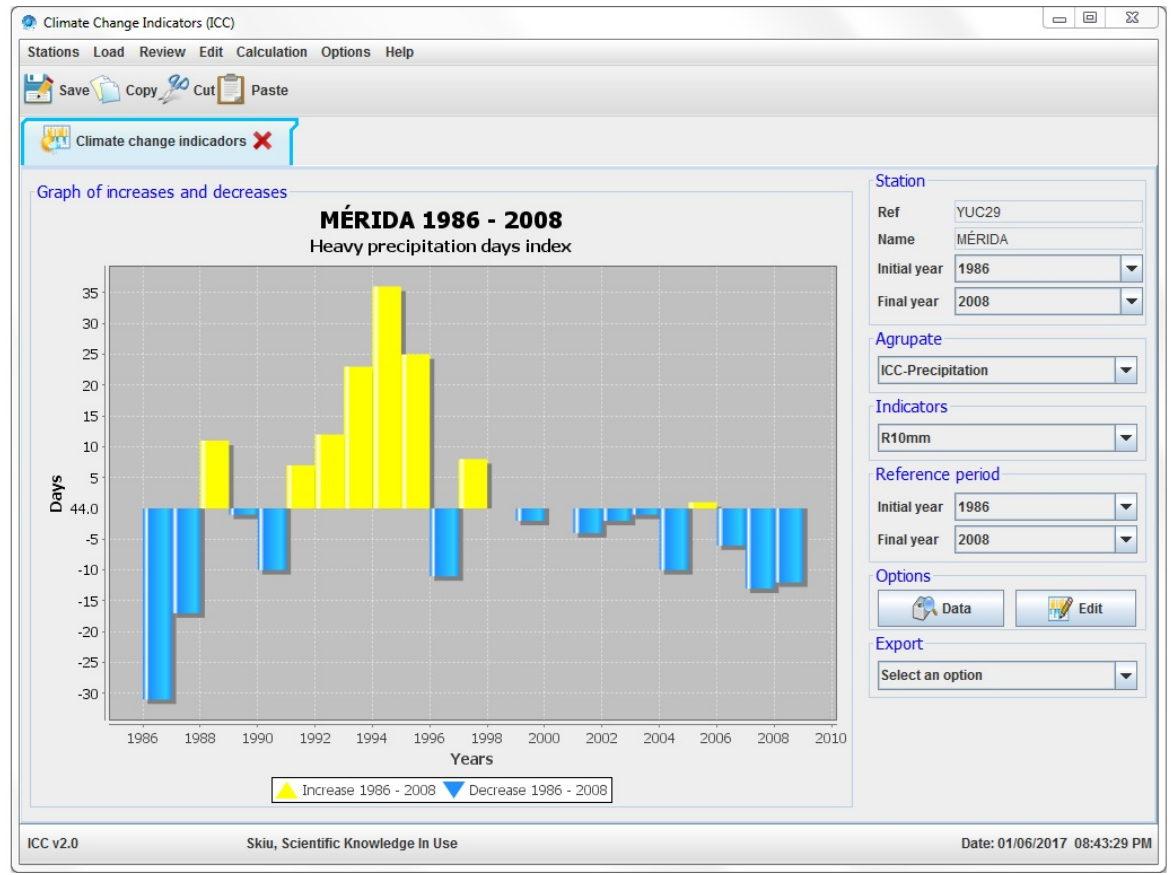

Figure 6. Deviations from the average climate change indicators using the ICC software.

occurrence are deemed abnormal (Beniston 2008). They correspond to the extremes of the normal distribution curve. To plot annual or monthly normal distribution graphs open the 'Calculations' menu and proceed to the corresponding submenu. A new tab will open, where one chooses the weather station, first and second reference periods, index and month to be analyzed. The data can be edited and saved in .pdf, .svg, .png formats.

The 'Data summary Clic-MD' submenu is used to generate summary tables with data on mean, minimum and maximum temperatures and precipitation for each month over the given range of years for the chosen weather station. The contents of the tables can be exported as .xls and.txt files. The interface language (English or Spanish) can be chosen through the 'Options' menu. The 'Help' menu provides information about the software (name, version, description), copyright, information about the company and authors.

ICC software offers a set of tools for storing and processing large sets of daily weather data. The software permits the calculation and analysis of 27 climate change indices and four indices for growing vines. The data can be analyzed over monthly, seasonal and annual time intervals to identify trends and climate anomalies. Understanding of climate change can help work out more effective strategies for mitigating the effects of extreme events in agriculture and ecosystems in general.

In comparison with other softwares (RClimTool, RClimPACT and RClimDex), ICC is friendlier and contains more functions, besides functioning as a database (Table 2) (Zhang and Yang 2004, Alexander et al. 2013, Herrera 2014). With this new ICC software researchers and technicians have a tool to analyze millions of data in seconds in a friendly environment and easy to interpret. ICC software might help in the implementation of mitigation measures for climate change based on the data of each location.

\section{ACKNOWLEDGEMENTS}

A skiu (Acts with science $S R L$ ) for the free license of the ICC software for the elaboration of the figures (https://www.actswithscience.com/). 


\section{LITERATURE CITED}

Alexander L, Yang H, Perkins S (2013) ClimPact. Indices and software. World Climate Programme, New South Wales University of Technology. 52p.

Bautista F, Pacheco A, Ayala G (2015) Indicadores de cambio climático con datos diarios. Scientific Knowledge In Use. México. 59p.

Beniston M (2008) Extreme climatic events and their impacts: examples from the Swiss Alps. In: Díaz HF, Murnane RJ (ed) Climate extremes and society. Cambridge University Press. New York. pp: 147-164.

Gbegbelegbe S, Chung U, Shiferaw B, Msangi S, Tesfaye K (2014) Quantifying the impact of weather extremes on global food security: A spatial bio-economic approach. Weather and Climate Extremes 4: 96-108

Gladstones J (2002) Viticulture and environment. Adelaide, Winetitles. Australia. 310p.

Hall M, Frank E, Holmes G, Pfahringer B, Reutemann P, Witten IH (2009) The WEKA Data Mining Software: An Update: SIGKDD Explorations 11: 10-18.

Herrera LL (2014) RClimTool user manual. Clima y sector agropecuario Colombiano, Colombia 17p.

Heim R (2015) An overview of weather and climate extremes - Products and trends. Weather and Climate Extremes 10: 1-9.

IPCC (2007) Climate change 2007: the physical science basis. Cambridge University Press, Cambridge, United Kingdom and New York, NY, USA. 104p.

Jahn M (2015) Economics of extreme weather events: Terminology and regional impact models. Weather and Climate Extremes 10: 29-39.

Karl TR, Nicholls N, Ghazi A (1999) CLIVAR/GCOS/WMO workshop on indices and indicators for climate extremes: Workshop summary. Climate Change 42: 3-4.

Kendall MG, Gibson JD (1990) Rank correlation methods, 5th edn. Oxford University Press. New York. 272p.

Ortiz-Solorio CA (1987) Elementos de agrometeorología cuantitativa con aplicaciones en la república mexicana. Departamento de Suelos, Universidad Autónoma de Chapingo. México. 326p

Peterson TC (2005) Climate change indices. World Meteorological Organization Bulletin 54: 83-86.

SE (2005) Norma NMX-I-045-NYCE-2005 tecnología de la información-software-procesos del ciclo de vida del software. Secretaría de Economía. Diarío Oficial de la Federación. http://www.dof.gob.mx/nota_detalle_popup.php?codigo=4918519. Date consulted: January 20, 2018.

Sen PK (1968) Estimates of the regression coeficient based on Kendall's tau. Journal of the American Statistical Association 63: 1379-1389.

Sepännen O, Fisk WJ, Lei-Gómez Q (2006) Effect of temperature on task performance in office environment. Lawrence Berkeley Laboratory. https://indoor.lbl.gov/sites/all/files/lbnl-60946.pdf. Date consulted: February 15, 2018.

Shannon HD, Motha RP (2015) Managing weather and climate risks to agriculture in North America, Central America and the Caribbean. Weather and Climate Extremes 10: 50-56.

Sheffield J, Wood EF (2011) Drought: PastProblems and Future Scenarios. Earthscan, London, p.210.

Snyder RL, De Melo-Abreu JP, Matulich S (2005) Frost protection: fundamentals, practice and economics. FAO. Rome 272p. 
Winkler AJ, Cook JA, Kliewer WM, Lider LA (1974) General Viticulture. 4th edn. Berkeley, CA: University of California Press. 710p.

Yan Z, Jones PD, Davies TD, Moberg A, Bergstrom H, Camuffo D, et al. (2002) Trends of extreme temperatures in Europe and China based on daily observations. Climate Change 53: 355-392.

Zhang GX, Yang F (2004) RClimDex (1.0) User manual. Climate research branch environment, Canada, Downsview, Ontario Canada. 
